\title{
A Comparative Study of the Corrosion Resistance of Incoloy MA 956 and PM 2000 Superalloys
}

\author{
Maysa Terada ${ }^{\mathrm{a}}$, Rogério Albuquerque Marques ${ }^{\mathrm{a}}$, Marina Magnani ${ }^{\mathrm{b}}$, Angelo Fernando Padilha ${ }^{\mathrm{c}}$, Isolda Costa ${ }^{\mathrm{a}, *}$ \\ anstituto de Pesquisas Energéticas e Nucleares, Centro Tecnológico de Ciência dos Materiais - CCTM, \\ Av. Lineu Prestes, 2242, CEP 05508-900, São Paulo, SP, Brazil \\ 'Laboratório Nacional de Luz Síncrotron - LNLS, CP 6192, CEP 13083-970, Campinas, SP, Brazil \\ 'Escola Politécnica da Universidade de São Paulo, Departamento de Engenharia Metalúrgica e de Materiais, \\ Av. Prof. Mello de Morais, 2463, CEP 05508-030, São Paulo, SP, Brazil
}

Received: September 3, 2009; Revised: October 25, 2010

\begin{abstract}
Austenitic stainless steels, titanium and cobalt alloys are widely used as biomaterials. However, new medical devices require innovative materials with specific properties, depending on their application. The magnetic properties are among the properties of interest for some biomedical applications. However, due to the interaction of magnetic materials with Magnetic Resonance Image equipments they might used only as not fixed implants or for medical devices. The ferromagnetic superalloys, Incoloy MA 956 and PM 2000, produced by mechanical alloying, have similar chemical composition, high corrosion resistance and are used in high temperature applications. In this study, the corrosion resistance of these two ferritic superalloys was compared in a phosphate buffer solution. The electrochemical results showed that both superalloys are passive in this solution and the PM 2000 present a more protective passive film on it associated to higher impedances than the MA 956.
\end{abstract}

Keywords: biomaterials, corrosion, Incoloy MA 956, PM 2000

\section{Introduction}

Metallic materials are widely used in dental implants, orthodontic appliances as bands, arch wires, ligature wires, hooks, tubes, brackets and springs, and orthopedic devices as implants and prosthesis for fractured bones healing ${ }^{1}$. However, the use of ferromagnetic alloys in orthopedic area is undesirable due to the size of the implant ${ }^{2,3}$, that can move or heat during MRI tests ${ }^{4}$. Most of these equipments generate magnetic fields of $1.5 \mathrm{~T}$ and some achieves $3.0 \mathrm{~T}$, equivalent to 50,000 times the magnetic field of the Earth ${ }^{3}$. It was proven that small devices, as dental implants and dental prosthesis attachments, are not affected by MRI tests ${ }^{5,6}$.

Both superalloys investigated in this study, Incoloy MA 956 and PM 2000, are ferromagnetic. These alloys were produced by mechanical alloying followed by hot extrusion. They have similar chemical compositions, but the literature shows differences in their kinetic oxidation and the oxide particle morphology, comparing samples heat treated at $1,100{ }^{\circ} \mathrm{C}$ for 100 hours. The authors attributed these differences to the aluminum amount in these alloys, as the PM 2000 has a larger $\mathrm{Al}$ concentration (1 wt. (\%)) than the Incoloy MA 9567.

Previous researches concluded that the Incoloy MA 956 has outstanding properties for applications as biomaterial ${ }^{8-10}$. The aluminum oxide layer formed at the outer porous layer favours osseointegration. Besides, the yttrium oxide improves the superalloy corrosion resistance ${ }^{11}$.

Recently, the PM 2000 has also been investigated for biomaterials applications, and its mechanical ${ }^{12}$ and magnetic properties have also been investigated ${ }^{13}$ as well its biocompatibility ${ }^{14,15}$.

\section{Experimental}

The superalloys investigated in the present study were produced by mechanical alloying and their chemical composition is shown in Table 1.
Samples with $0.90 \mathrm{~cm}^{2}$ were cut from a transversal section of extruded cylindrical bars $(\mathrm{d}=30 \mathrm{~mm})$ of the Incoloy MA 956. The PM 2000 samples were taken from a transversal section of extruded cylindrical bars $(\mathrm{d}=5 \mathrm{~mm})$. The area of the samples was $0.196 \mathrm{~cm}^{2}$.

All the samples were ground with silicon carbide paper up to $\# 4,000$, then rinsed with deionised water and immersed in PBS solution at $25^{\circ} \mathrm{C}$, whose composition is shown in Table 2 . Initially few tests were carried out at $37^{\circ} \mathrm{C}$ and others at $25^{\circ} \mathrm{C}$, but after comparing the results and the observation that there was no significant effect of the increase in temperature from 25 to $37^{\circ} \mathrm{C}$ for the two tested materials, the electrochemical tests were performed at $25^{\circ} \mathrm{C}$. Samples were analyzed by electrochemical techniques as EIS, Mott-Schottky approach and XPS.

The electrochemical tests were performed using a threeelectrode cell set-up, with a platinum wire and a saturated calomel electrode (SCE) as counter and reference electrodes, respectively. Electrochemical impedance spectroscopy (EIS) and Mott-Schottky approach measurements were accomplished using a 1255 Solartron frequency response analyzer coupled to an EG\&G 273 A potentiostat. All EIS measurements were obtained in the potentiostatic mode at the stabilized open circuit potential after 48 hours of immersion. The amplitude of the sinusoidal signal was $10 \mathrm{mV}$ (rms) and the investigated frequency was from $100 \mathrm{kHz}$ to $10 \mathrm{mHz}$, with an acquisition rate of 6 points per decade. After the EIS tests, potentiodynamic polarization measurements were obtained in the range from the open circuit potential (OCP) up to the current reached $10 \mathrm{~mA} \cdot \mathrm{cm}^{-2}$, at a scan rate of $1 \mathrm{mV} \cdot \mathrm{s}^{-1}$. After polarization tests, the tested surface was analyzed by scanning electron microscopy (SEM) using a Philips XL30 microscope. The Mott-Schottky diagrams were taken with a Gamry PCI 4500 potentiostat. The reproducibility of the results was investigated by carrying out five tests for each material studied and the results were found to be reproducible. 
Table 1. Chemical composition (wt. (\%)) of Incoloy MA 956 and PM 2000.

\begin{tabular}{ccccccccccccc}
\hline & $\mathrm{C}$ & $\mathrm{Cr}$ & $\mathrm{Ni}$ & $\mathrm{Mo}$ & $\mathrm{Si}$ & $\mathrm{Mn}$ & $\mathrm{Al}$ & $\mathrm{Y}$ & $\mathrm{Ti}$ & $\mathrm{Fe}$ \\
\hline PM 2000 & - & 22.01 & 0.08 & 0.31 & - & 0.12 & 5.59 & 0.50 & 0.56 & $\mathrm{Bal}$ \\
Incoloy MA 956 & 0.02 & 21.26 & 0.09 & 0.16 & 0.07 & 0.14 & 4.61 & 0.42 & 0.39 & Bal. \\
\hline
\end{tabular}

Table 2. Chemical composition (g. $\left.\mathrm{L}^{-1}\right)$ of the phosphate buffer solution (PBS), $\mathrm{pH}=7.0$.

\begin{tabular}{ccc}
\hline $\mathrm{NaCl}$ & $\mathrm{Na}_{2} \mathrm{PO}_{4}$ & $\mathrm{KH}_{2} \mathrm{PO}_{4}$ \\
\hline 8.77 & 1.42 & 2.72 \\
\hline
\end{tabular}

\section{Results and Discussion}

The EIS results of both tested alloys after 48 hours immersion in PBS are shown in Figure 1. The impedance modulus values at $0.01 \mathrm{~Hz}$ were of the order of $10^{5} \Omega . \mathrm{cm}^{2}$ for both alloys with higher impedances associated to the PM 2000 alloy comparatively to the MA 956 one. The Bode phase angle diagram for the first alloy show a very large peak from $10^{2} \mathrm{~Hz}$ to approximately $1 \mathrm{~Hz}$, indicating the interaction of more than one time constant. For the MA 956 alloy the high frequency peak starts at lower frequencies comparatively to the PM 2000 alloy, suggesting a less protective oxide film associated to the first in comparison with the last. These results were supported by those obtained from fitting procedure.

The EIS diagrams were fitted using the equivalent electric circuits shown in Figure $2 \mathrm{a}$ and $2 \mathrm{~b}$. According to results reported in literature ${ }^{16}$, the model proposed in Figure 2a represents the Incoloy MA 956 immersed in Hanks's solution and characterizes a passive system ${ }^{16,17}$. It has been stated that the presence of only one time constant in the EIS results of the Incoloy MA 956 is due to the presence of an alumina layer on the alloy surface ${ }^{9}$. However, the literature also reports X-ray photoelectron spectroscopy (XPS) results of as received Incoloy MA 956 showing a duplex oxide layer, with an inner chromium rich layer and an outer iron rich layer, with little amounts of alumina and without titanium or yttrium oxides ${ }^{18}$.

In the present study, the electric equivalent circuit shown in Figure $2 b$ which has also been related in the literature ${ }^{19-21}$ to stainless steels, presented much better fitting to the experimental results of both tested alloys than the ones proposed by Escudero et al.9,18. This circuit has been attributed to a duplex oxide layer, with an inner layer rich in chromium and the outer one, rich in iron and nickel ${ }^{19-21}$. Nevertheless, other authors ${ }^{16,22,23}$ proposed that the R-CPE pair that corresponds to the high frequency results is associated to the oxide passive film whereas that $\mathrm{R}-\mathrm{C}$ pair associated to the low frequency data is related to interfacial processes and charging of the double layer at the stainless steel substrate-oxide interface.

Table 3 presents the resistances, capacitances, CPE and CPE exponent values obtained from fitting the results of both alloys to the equivalent circuit shown in Figure 2b. In all cases, the agreement between experimental and fitted data was very good. The capacitance values obtained at the low frequencies for the PM 2000 alloy is typical of double layer capacitances (30-50) $\mu \mathrm{F}$. However, for the MA 956 alloy, the corresponding capacitance values were too high (order of $110 \mu \mathrm{F}$ ) and typical of oxides. Consequently, it is proposed that the characteristics of the passive film on both tested alloys are dissimilar due to the differences in the composition of tested alloys, as shown in Table 1, mainly in the contents of $\mathrm{C}, \mathrm{Cr}, \mathrm{Mo}, \mathrm{Al}$ and $\mathrm{Ti}$, with lower amounts of $\mathrm{C}$, and slightly higher of $\mathrm{Cr}$, Mo and Ti being associated to the PM 2000 alloy. This distinction reflects on the properties of the oxide layer and, consequently, on the electrochemical results which are dependent on the oxide film properties leading to the two proposed explanations suggested in the present study.

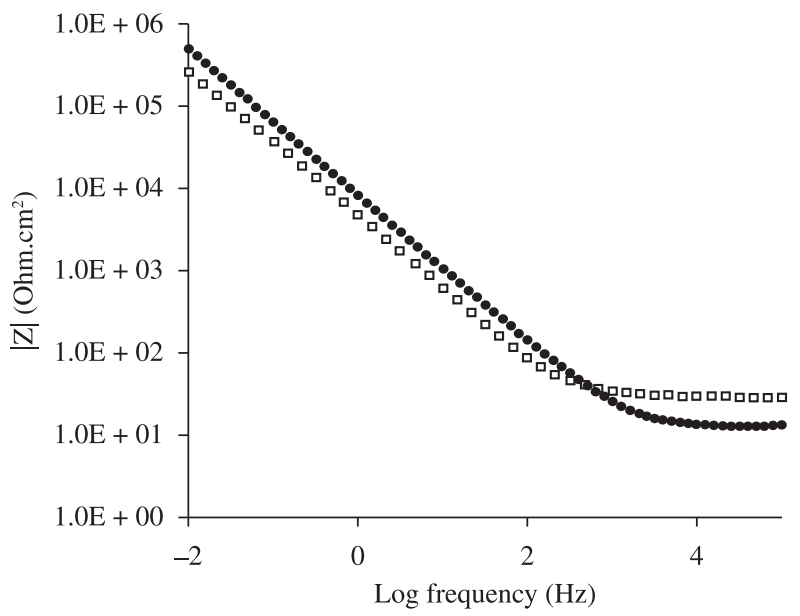

(a)

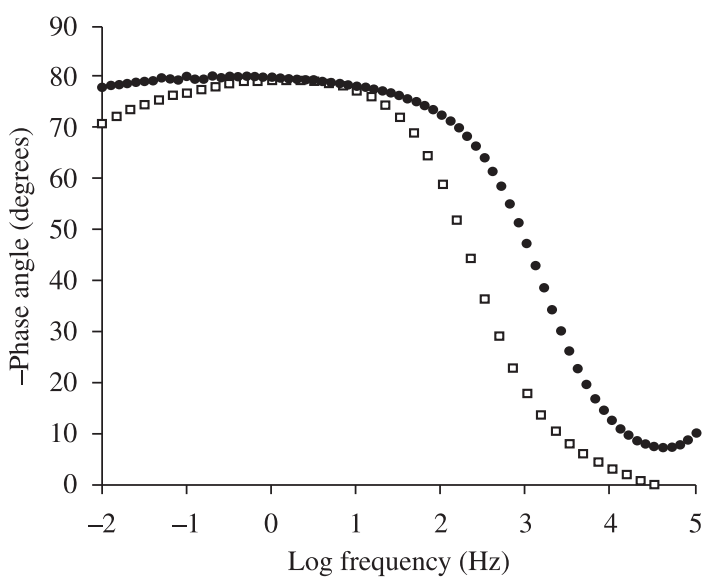

(b)

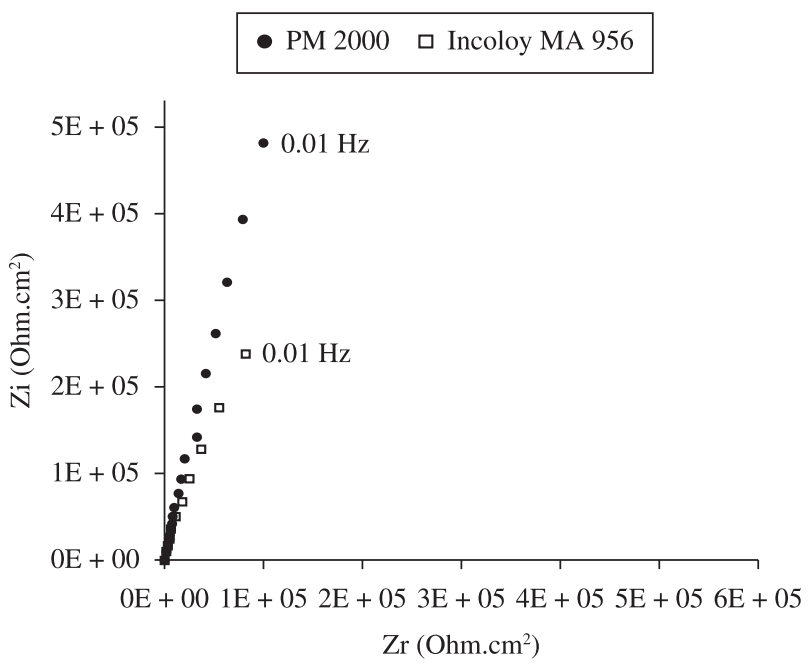

(c)

Figure 1. EIS diagrams obtained for the Incoloy MA 956 and the PM 2000 after 48 hours of immersion in PBS at $25^{\circ} \mathrm{C}$. a) $\mathrm{Z}$ modulus; b) phase angle; and c) Nyquist diagrams. 
Considering the composition of the PM 2000 alloy with comparatively higher $\mathrm{Cr}$, Mo and Ti contents than the MA 956 alloy, besides very low $\mathrm{C}$ amounts, it is expected that a highly protective passive film, with also very low thickness, due to hindered transport

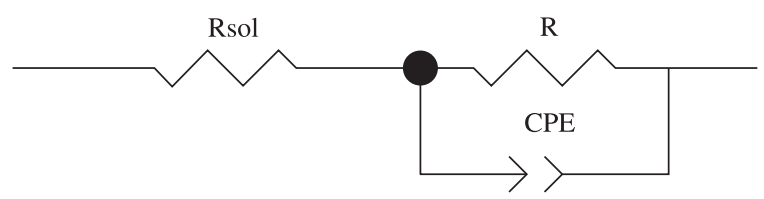

(a)

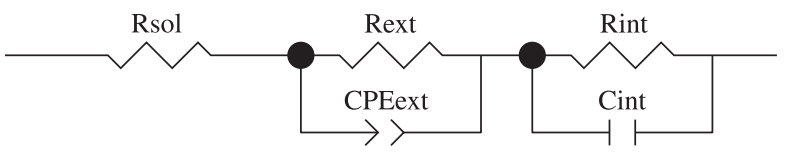

(b)

Figure 2. Equivalent electric circuits used to fit the EIS results of MA 956 and PM 2000 alloys.

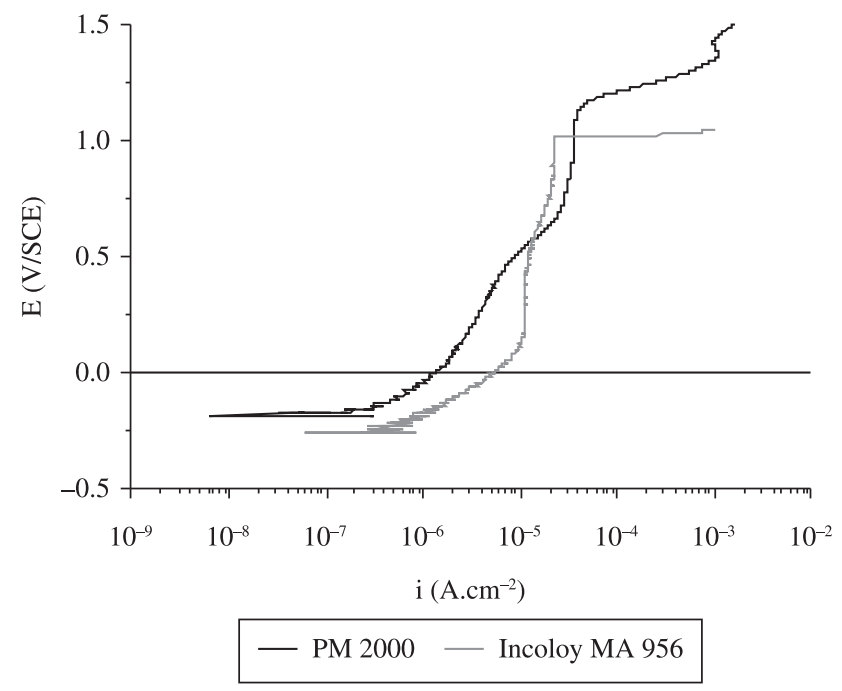

Figure 3. Potentiodynamic polarization curves for Incoloy MA 956 and PM 2000 obtained after 48 hours of immersion in PBS solution. through it, forms on the PM 2000 alloy. The model adopted to interpret the results of this alloy was the one that associates the high frequency results to the oxide layer $\left(\mathrm{R}_{\mathrm{ox}}-\mathrm{CPE}_{\mathrm{ox}}\right)$ and the low frequency ones to the charge transfer process and the charging of the double layer $\left(\mathrm{R}_{\mathrm{ct}}-\mathrm{C}_{\mathrm{dl}}\right)$ at the substrate-oxide film interface. However, for the MA 956 alloy, the EIS results indicated a less protective film than for the PM 2000 and, consequently, easier species transport through it. This hypothesis was supported by the results presented in the polarization curves shown in Figure 3, where larger passive currents are associated to the MA 956 alloy comparatively to the PM 2000 one. The more facilitated transport through the film on MA 956, in turn, favors film growth and leads to a thicker and more defective external layer likely richer in the elements with higher diffusion rates through the oxide. The EIS results for the MA 956 alloy show capacitance values typical of oxides for both time constants, at higher and lower frequencies, likely related to the external and more defective oxide layer and the inner and more protective layer, respectively.

The CPE exponents corresponding to the high frequencies time constant were around 0.8 for both tested materials. This suggests a non-uniform oxide film/layer presenting discontinuities where either the metallic substrate or an inner oxide might be exposed to the electrolyte. The results from the fitting procedure also indicated a more resistant oxide film on the surface of PM2000 than on the MA 956 alloy.

The potentiodynamic polarization curves obtained for both studied alloys shown in Figure 3 reveal that lower current densities, nobler corrosion potentials and higher film breakdown potentials were associated to the PM 2000 comparatively to the Incoloy MA 956. This last alloy presented breakdown potentials around $1.1 \mathrm{~V}_{\mathrm{SCE}}$

Table 3. Comparison of the values of the components of the equivalent electric circuit (EEC) associated to Figure 2b, for Incoloy MA 956 and the PM 2000 alloys in PBS solution.

\begin{tabular}{cccc}
\hline $\begin{array}{c}\text { Component } \\
\text { of EEC }\end{array}$ & PM 2000 & $\begin{array}{c}\text { Component } \\
\text { of EEC }\end{array}$ & $\begin{array}{c}\text { Incoloy } \\
\text { MA 956 }\end{array}$ \\
\hline $\mathrm{R}_{\text {sol }}\left(\Omega \cdot \mathrm{cm}^{2}\right)$ & 12.53 & $\mathrm{R}_{\text {sol }}\left(\Omega \cdot \mathrm{cm}^{2}\right)$ & 16.75 \\
$\mathrm{CPE}_{\text {ox }}\left(\mathrm{F}^{-} \mathrm{cm}^{-2} \cdot \mathrm{s}^{-\mathrm{n}}\right)$ & $6.52 \times 10^{-5}$ & $\mathrm{CPE}_{\mathrm{ext}}\left(\mathrm{F} \cdot \mathrm{cm}^{-2} \cdot \mathrm{s}^{-\mathrm{n}}\right)$ & $1.74 \times 10^{-4}$ \\
$\mathrm{R}_{\mathrm{ox}}\left(\Omega \cdot \mathrm{cm}^{2}\right)$ & $7.08 \times 10^{4}$ & $\mathrm{R}_{\text {ext }}\left(\Omega \cdot \mathrm{cm}^{2}\right)$ & $1.90 \times 10^{4}$ \\
$\mathrm{n}$ & 0.79 & $\mathrm{n}$ & 0.82 \\
$\mathrm{C}_{\mathrm{dl}}\left(\mathrm{F} \cdot \mathrm{cm}^{-2} \cdot \mathrm{s}^{-1}\right)$ & $3.44 \times 10^{-5}$ & $\mathrm{C}_{\text {int }}\left(\mathrm{F} \cdot \mathrm{cm}^{-2} \cdot \mathrm{s}^{-1}\right)$ & $1.10 \times 10^{-4}$ \\
$\mathrm{R}_{\mathrm{ct}}\left(\Omega \cdot \mathrm{cm}^{2}\right)$ & $4.54 \times 10^{6}$ & $\mathrm{R}_{\text {int }}\left(\Omega \cdot \mathrm{cm}^{2}\right)$ & $5.52 \times 10^{5}$ \\
\hline
\end{tabular}

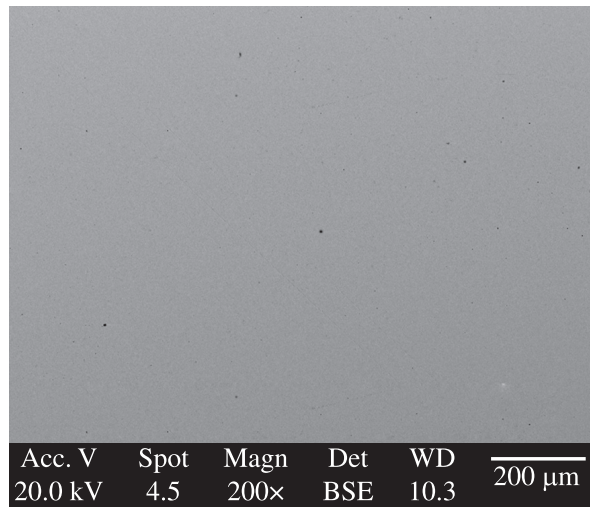

(a)

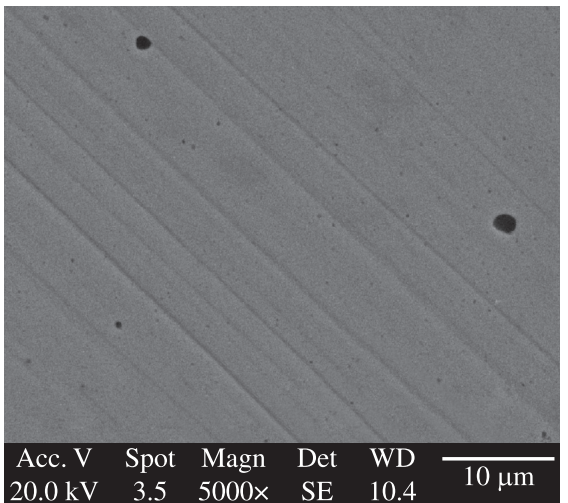

(b)

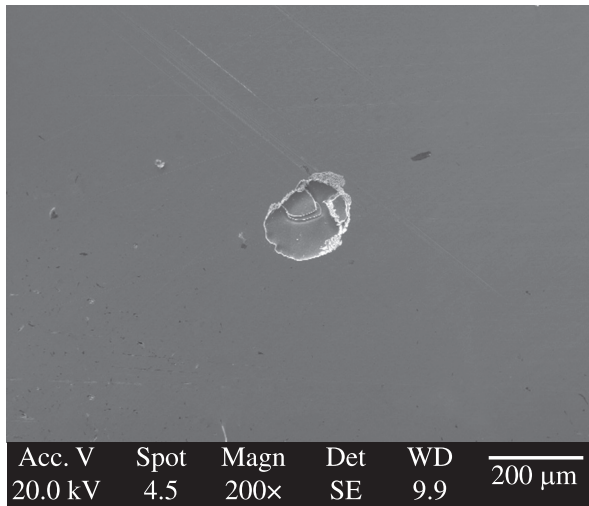

(c)

Figure 4. SEM micrographs of surface of the superalloys investigated after polarization tests. a) PM 2000; b) same at higher magnifications; and c) MA956, showing pits on the surface of the tested samples. 


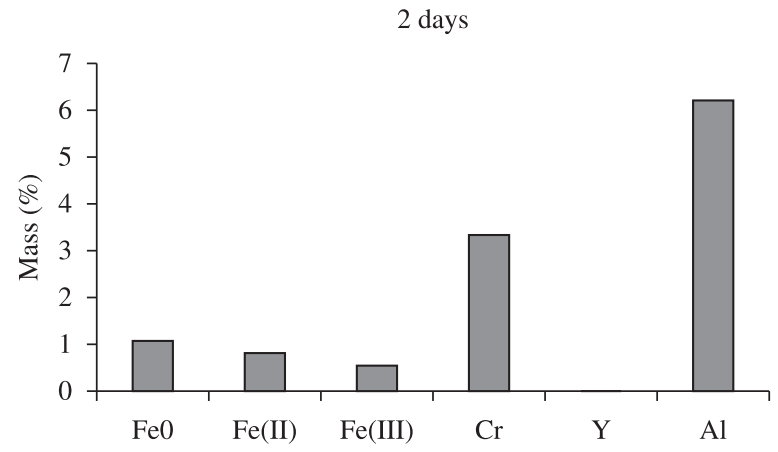

Figure 5. Quantitative XPS analyses on the surface of the PM2000 SS after 2 days of immersion in PBS solution at $25^{\circ} \mathrm{C}$. Fe (III), $\mathrm{Cr}$ (total), $\mathrm{Y}$ and $\mathrm{Al}$ (total).

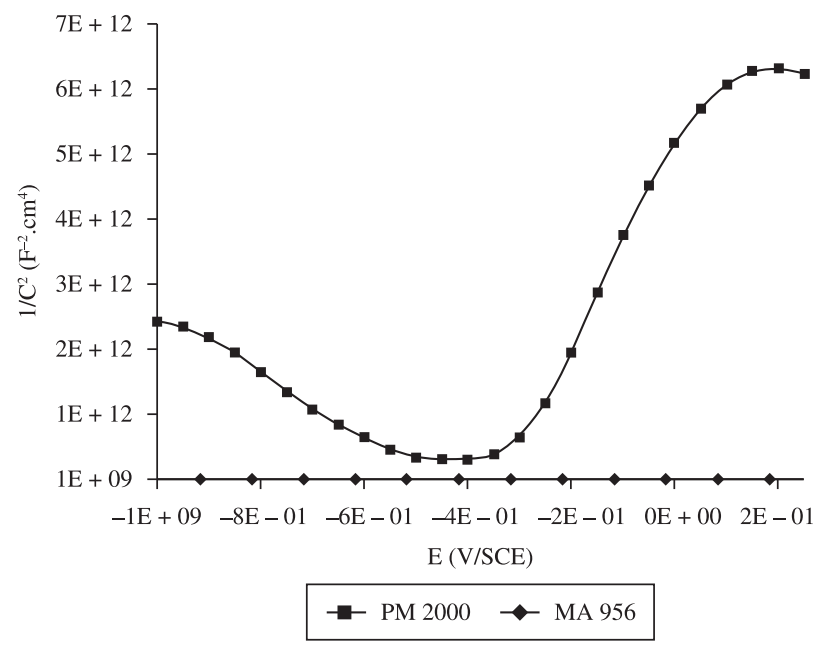

(a)

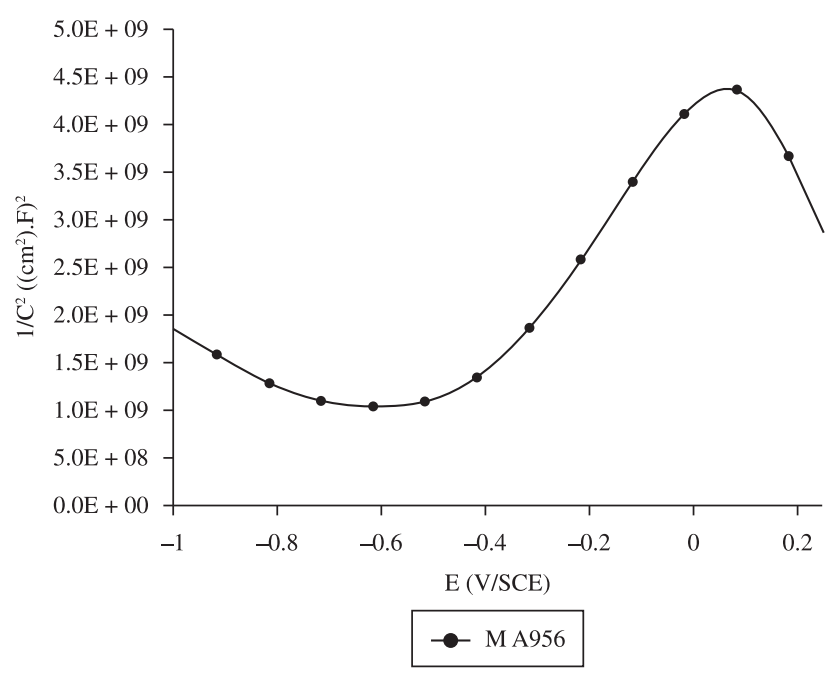

(b)

Figure 6. Mott-Schottky approach for the PM 2000 and MA 956 after 2 days of immersion in a PBS solution at $25^{\circ} \mathrm{C}$.

whereas the PM 2000 only showed large current increase typical of film breakdown at potentials of approximately $1.2 \mathrm{~V}_{\mathrm{SCE}}$. The increase in current density at this last potential could be due to the oxygen evolution reaction instead of pitting. The samples were analyzed by scanning electron microscopy (SEM) after anodic polarization tests to investigate whether pits were formed on the alloy surface. Figure 4 shows the surfaces of both alloys after have been polarized.
The PM 2000 alloy reveals a large number of very small pits $(\mathrm{d}<2 \mu \mathrm{m})$ whereas only one pit was seen on the Incoloy MA 956 surface, which was about one hundred times larger than the pits on the PM 2000. An unique pit was found on the Incoloy MA 956 alloy after anodic polarization, for all samples tested. The singularity of only one pit on the Incoloy MA 956 needs further investigation.

XPS analysis was carried out on PM 2000 alloy specimens that were immersed for 48 hours in the PBS solution and the results are presented in Figure 5. The results show that the outer passive film (it must be pointed out that only the external surface was analyzed, since sputtering was not carried out) is aluminum enriched. In fact, aluminum is added to this type of alloys to favor the growth of an outer porous oxide layer. It is believed that an inner chromium enriched layer is present on the oxide film. XPS analysis coupled to sputtering is necessary to confirm this hypothesis and it will be carried out in the future.

XPS results also indicate that the surface film was mainly composed of $\mathrm{Fe}(\mathrm{II})$ and $\mathrm{Fe}$ (III) oxides and hydroxides, together with $\mathrm{Cr}(\mathrm{III})$ oxides and traces of $\mathrm{Cr}(\mathrm{VI})$ oxide. Chlorides were not detected. No other elements were detected and the composition is typical of a duplex passive film.

The presence of an oxide film with a duplex structure was also indicated by Mott-Schottky results, as Figure 6 shows. The presence of a film with a duplex nature has been previously reported in the literature and it was confirmed by the results of the present study shown in Figure 6. The positive and negative slopes of the diagrams can be related to the oxide layers that compose the duplex passive film and differ in the elements in which they are enriched, once they present different conductive properties. An extrinsic semiconductor p-type (acceptor) oxide can be characterized by the excess of positive charges due to vacancies or electronic holes. The extrinsic semiconductor oxides n-type (donor) present excess of negative charges due to metallic ions vacancies. Both of them are named dopants and can be related to the number of the defects of the superficial oxide layer ${ }^{19,24,25}$. The number of donors $\left(\mathrm{N}_{\mathrm{D}}\right)$ and acceptors $\left(\mathrm{N}_{\mathrm{A}}\right)$ of the passive film was calculated from the positive and negative slope using the Mott-Schottky approach. The amount around $10^{21}$ dopants. $\mathrm{cm}^{-3}$ of the MA 956 is one order lower than the values calculated for $316 \mathrm{~L} \mathrm{SS}$ by Montemor et al. ${ }^{[21]}$ and the $10^{18}$ dopants. $\mathrm{cm}^{-3}$ of the PM2000 suggests that this SS has a 1,000 times more homogeneous oxide layer.

The Mott-Schottky results suggest that the amount of dopants in the two alloys tested might be the reason for the protective characteristics of the film formed with superior corrosion resistance properties associated to the PM 2000 alloy.

\section{Conclusions}

The electrochemical tests and surface observation after polarization tests showed that the passive film on the PM 2000 alloy is more resistant to corrosion than the Incoloy MA 956. Higher impedances were associated to the PM 2000 alloy and the potentiodynamic polarization curves showed higher corrosion rates associated to the Incoloy MA 956 comparatively to the PM 2000, supporting the EIS results.

It is proposed that the difference in the $\mathrm{Al}$ content ( $\mathrm{Al}$ content in PM 2000 is 1 wt. (\%) higher than in the Incoloy MA 956) might be one of the reasons for this result, but further investigation is necessary to confirm this hypothesis. The electric equivalent circuit proposed suggests that both superalloys have a passive oxide film with a duplex nature, composed of an inner and more resistant layer, and an outer layer. 


\section{Acknowledgements}

The authors acknowledge CAPES and FAPESP (Grant 08/54836-0) for financial support to Dr. Maysa Terada.

\section{References}

1. Oh KT, Kim KM and Kim KN. Properties of super stainless steel (UNS No. S32050) wire for orthodontic application. Journal of Dental Research 2001; 80(4): 1355.

2. New pfj, rosen br, brady tj, Buonanno fs, kistler jp, burt ct et al. potential hazards and artifacts of ferromagnetic and nanoferromagnetic surgical and dental materials and devices in Nuclear Resonance Imaging. Radiology. 1983; 147:139-148.

3. Woods TO. Stainless steels for medical and surgical applications. In ASTM Symposium, EUA; 2002. p. 82-90

4. Shellock FG and Curtis JS. MR Imaging and biomedical implants, materials, and devices: an update review. Radiology. 1991; 180:541-550.

5. Iimuro FT. Magnetic Resonance Imaging artifacts and the magnetic attachment system. Dental Materials Journal. 1994; 13(1):76-88.

6. Devge C, Tjellström A and Nellström H. Magnetic Resonance Imaging in patients with dental implants: a clinical report. The International Journal of Oral \& Maxillofacial Implants. 1997; 12(3).

7. González-Carrasco JL, García-Alonso MC, Montealegre MA, Escudero ML and Chao J. Comparative study of the alumina-scale integrity on MA 956 and PM 2000 alloys. Oxidation of Metals. 2001; 55(3-4):209-221.

8. Escudero ML and González-Carrasco JL. In vitro corrosion behavior of MA 956 superalloy. Biomaterials. 1994; 15(14):1175-1180.

9. Escudero ML, González-Carrasco JL, García-Alonso MC and Ramirez E. Eletrochemical impedance spectroscopy of preoxidized MA 956 superalloy during in vitro experiments. Biomaterials. 1995; 16(9):735-740.

10. Escudero ML, López MF, Ruiz J, García-Alonso MC and Canahua H. Comparative study of the corrosion behavior of MA-956 and conventional biomaterials. Journal of Biomedical Materials Research. 1996; 31(3):313-317.

11. Ginesan P and Smith GD. Oxide scale formation on selected candidate combustor alloys in simulated gas turbine environments. Journal of Materials Engineering. 1988; 9:337-343.

12. González-Carrasco JL, Ciapetti G, Montealegre MA, Pagani S, Chao $\mathrm{J}$ and Baldini N. Evaluation of mechanical properties and biological response of an alumina-forming Ni-free ferritic alloy. Biomaterials. 2005; 26:3861-3871
13. Flores MS, Ciapetti G, González-Carrasco JL, Montealegre MA, Multigner M, Pagani S et al. Evaluation of magnetic behaviour and in vitro biocompatibility of ferritic PM2000 alloy. Journal of Materials Science: Materials in Medicine. 2004; 15(5):559-565.

14. Ciapetti G, González-Carrasco JL, Montealegre MA, Pagani S, Chao J and Baldini N. Quantitative assessment of the response of osteoblast- and macrophage-like cells to particles of $\mathrm{Ni}$-free Fe-base alloys. Biomaterials. 2003; 26(8):849.

15. Ciapetti G, González-Carrasco JL, Montealegre MA, Pagani S and Baldini N. Enhanced osteoblast functions on new Fe-base Ni-free alloys containing nanoparticles. In: II Iberian Congress on Biomaterials and Biosensors; 2004; Evora, Portugal. p. 7.

16. Ge H, Zhou G and Wu W. Passivation model of 316 stainless steel in simulated cooling water and the effect of sulfide on the passive film. Applied Surface Science. 2003; 211(1-4):321-334.

17. Wolynec S. Técnicas eletroquímicas em corrosão.São Paulo: EDUSP; 2003.

18. Lopez MF, Gutierrez A, García-Alonso MC and Escudero ML. Surface analysis of a heat-treated, Al-containing, iron-based superalloy. Journal of Materials Research. 1998; 13(12):3411-3416.

19. Antunes RA. Caracterização do comportamento frente à corrosão de um aço inoxidável austenítico para aplicações biomédicas com revestimentos $P V D$ de TiN, TiCN e DLC. [Tese]. São Paulo: Instituto de Pesquisas Energéticas e Nucleares; 2006.

20. Hakiki NE, Boudin S, Rindot TB and Da Cunha Belo M. The electronic structure of passive films formed on stainless steels. Corrosion Science. 1995; 37(11):1809-1822.

21. Montemor MF, Ferreira MGS, Hakiki NE and Da Cunha Belo M. Chemical composition and eletronic structure of the oxide films formed on 316L stainless steel and nickel based alloys in high temperature aqueous environments. Corrosion Science. 2000; 42(9):1635-1650.

22. Azumi K, Ohtsuka T and Sato N. Impedance of iron electrode passivated in borate and phosphate solutions. Transactions of the Japan Institute of Metal. 1986; 27(5):382-392.

23. Gerisher H. Models for the discussion of the photo-electrochemical response of oxide layers on metals. Corrosion Science. 1989; 29(2-3):257-266.

24. Terada M. Correlação entre microestrutura e corrosão de aços inoxidáveis avançados em meios fisiológicos. [Tese]. São Paulo: Escola Politécnica da Universidade de São Paulo; 2008.

25. Terada M, Marques RA, Saliba-Silva AM, Padilha, AF and Costa, I. The comparison of the corrosion resistance of advanced ferritic stainless steels by Mott-Schottky approach. Materials and Corrosion. 2010; in press. 